\title{
Model Innovation of Process Based on the Standard e-commerce International GS1
}

\author{
${ }^{1}$ Giovanny Mauricio Tarazona Bermúdez, ${ }^{1}$ Luz Andrea Rodríguez Rojas, ${ }^{2}$ Cristina B Pelayo, \\ ${ }^{2}$ Oscar Sanjuan Martínez \\ ${ }^{\text {I}}$ Faculty of Engineering, District University Francisco José de Caldas, Bogotá, Colombia \\ ${ }^{2}$ Computer Science Department, University of Oviedo, Oviedo, Spain
}

\begin{abstract}
This article focuses on the design and characterization of management model for MSMEs, based on ecommerce and the GS1 international e-com standard. The first part contextualizes electronic commerce and its impact on domestic industry, and briefly describes the B2B e-commerce model used in Colombia. Subsequently the first step to apply the model is presented, which corresponds to the design of a diagnostic methodology that evaluates the technological, technical, commercial and administrative aspects of the organization; after that are exposed the results of the pilot experiment performed on a MSME from Bogota, and finally will be explained the procedures for the implementation of the model.
\end{abstract}

Keyword s- e-commerce, Technology Management, ICT, Knowledge Management, MSMEs.

\section{INTRODUCTION}

$\mathrm{T}$ oday innovation in processes supported by technological advances are a decisive factor in the success of business organizations. [1]It is evident that the use of technology for production operations, administrative or any kind has become a tool rather than necessary, indispensable for achieving the mission of a company purposes. [2] [3]

Rapid technological progress in recent years have not only impacted the industry and production automation, but also in logistics and marketing of products, has opened the field to information technology developments in both software and hardware, [4] coupled with advances in information technology and communications are the backbone of business processes on the web, particularly electronic commerce, which has emerged as an essential tool for successful companies in a global market. [5]

The ability to sell their products to thousands or perhaps millions of people is the obsession of a business as a basic condition for sustainability, and in turn what might seem virtually unattainable for most Colombian MSMEs, given the conditions of a Latin American country with a huge digital divide and developing economy. This is why the implementation of electronic commerce as a factor for innovation in management processes in these companies is postulated as one of the alternatives that can bring major benefits to this productive sector. [6]

It is important to characterize the categories of electronic commerce (Fig. 1. Methods of Electronic Business) and to contextualize the model designed and proposed in this article, within Colombia:

\section{Company-Company}

Here are the companies that use a network as a means to make the purchase orders and receive invoices from their suppliers, and with it all other electronic documents for the purchase order cycle to be completed.

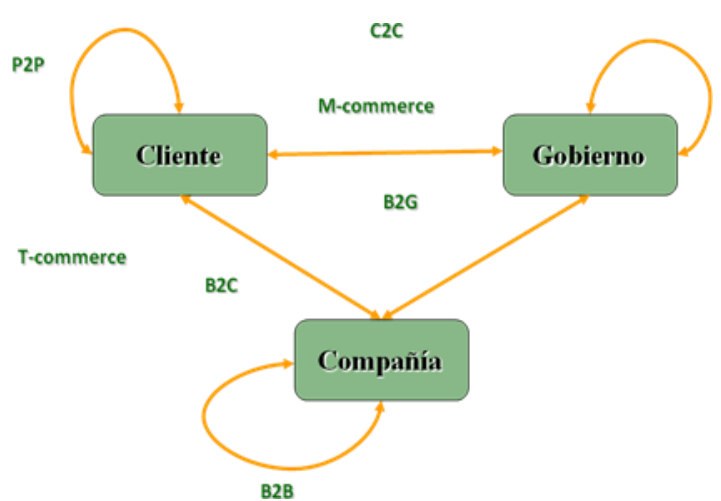

Fig. 1. Categories of Electronic Business

\section{Company-customer}

Through the network, the company offers its products to customers who accessed the quantity you need, do hereby numerous products currently marketed.

\section{Company-Administration}

Here are the transactions carried out between different companies and government organizations, such as paying taxes, even though this is true in its infancy.

Customer-Administration

Here the user would communicate with state agencies to make their tax payments or social assistance, although this is not instituted yet, it's about time it is.

\section{Customer-Customer}

It was one of the first e-business practices appeared in the early 90's web pages are little known and specialized. Your maximum evolution came with the popularization of e-bay that gives the possibility of direct sales between its users. [7] 
T-commerce: The idea is to let users buy products over the Internet but through their interactive television, instead of over a phone (m-commerce) or through a PC or PDA.

$B 2 B$ (business-to-business): On the Internet, also known as e-biz, is the exchange of products, services, or information between businesses rather than between businesses and consumers.

Peer to Peer. In a P2P network, the "peers" are computer systems which are connected to each other via the Internet. Files can be shared directly between systems on the network without the need of a central server. In other words, each computer on a P2P network becomes a file server as well as a client.

From this conceptual base, the project proposes applying information technologies, combined with academic concepts and skills in marketing and logistics in order to design and characterize innovative marketing processes for MSMEs producing and distribution of sweets, snacks and canned Bogotá based on the standard e-commerce GS1 International, as a means to leverage the leading commercial chain stores in the country.

\section{II.PROCEDURE FOR PAPER SUBMISSION CHARACTERIZATION OF E-COMMERCE NATIONAL MODEL "B2B"}

International GS1 is an organization of 105 institutions in over 150 countries, serving various industrial and economic sectors, by managing logistics standards to promote the efficiency of Value Networks. At home, GS1 Colombia manages the international standards of bar code (barcode), electronic commerce (e-com), synchronization of databases (GDSN) and the Electronic Product Code (EPCglobal).

Given this, it is essential that any model that seeks to facilitate the access of MSMEs to these markets is based on these standards. [8] The following will highlight the main features of the B2B model used in Colombia, approach having as standard documents that are used and their implementation within the business cycle, logistical and financial e-commerce. in the figure. 2. Logistics Cycle entitled B2B e-commerce in Colombia, sample characteristics.
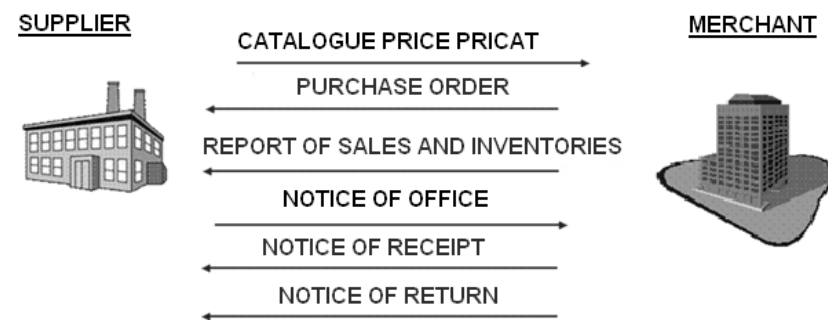

Fig. 2. Logistics Cycle B2B e-Commerce in Colombia.

The first step is to generate a catalog business called PRICAT, arising from the negotiations made between the supplier and dealer in a traditional way. In this negotiation the products are down to sell outlets where available and their sales prices are set.
PRICAT The electronic document should be based on the EDI standard, and should be sent to CABASnet it is the electronic product catalog that Colombia, Costa Rica, El Salvador, Guatemala, Honduras, Nicaragua, Paraguay and Peru, have been developed for the benefit of centralization and synchronization information to clients and suppliers use daily.[9]

Customers, suppliers, distributors and chains currently benefit from having a tool at their disposal to facilitate commercial transactions between business partners, both locally and internationally.

CABASnet who will review the structure of the catalog and sent to the e-commerce customers (chain stores, supermarkets, hypermarkets, etc.) through the interface CEN (Center for electronic business) which is operated by IBC, a group company Assenda S. Carvajal A. In Figure 3 PRICAT document processing, exemplified the expected workflow

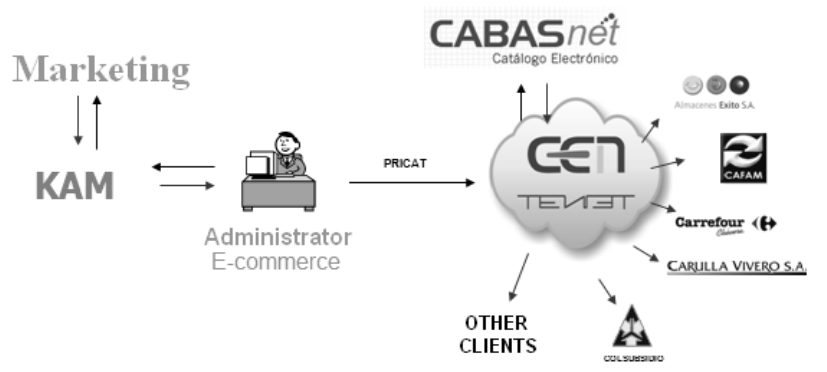

Fig. 3. Document Processing PRICAT

When a product has been coded in-store customer through the application of a PRICAT proceed from the client to generate and transmit a purchase order, the order will obey the expected demand for the product by the end customer in point of sale. The purchase order must be sent fully in the international standard GS1 EDI. [10]

After receiving the purchase order, the supplier shall dispatch in lead time, you cannot advance or delay in delivery of the order. One day before delivery at the point of sale, the producer must send a notice of release, electronic document which specifies the types of packaging of goods, total units shipped, the final destination of the goods, among others. Following the dispatch to print a bar code which records the information of the standard. [11]

The notice of receipt is an electronic document with the supermarket chains which suppliers indicate the total number of articles (products) that were received from a specific purchase order. This document is the basis for producing and sending invoices electronically from suppliers.

A key part of e-commerce model as the centerpiece of the proposal of innovative processes with large supermarket chains in the country is easy for suppliers to verify the behavior of the demand for their products. This facility provides two tools: a) purchase orders transmitted daily or as often as deemed necessary provider, or b) the sales and inventory information sent weekly supermarket chains through weekly or monthly sales and inventory report.

The agents involved in this innovative process serve three (3) main roles: Manager E-Commerce acts as the support using tools and techniques to electronic information exchange, 
manage and control electronic order management and physical, among others. The commercial agent is responsible for assembling and transmitting orders at the point of sale, track the behavior of demand and inventories, and maintain close business relationship with customers at point of sale. Finally, the Key Account Manager (KAM) is the one in charge of trade negotiations (products, pricing, promotions) with customers, maintain control and review of sales and inventory reports, update and ensure the availability of official price lists and catalogs to customers.

\section{DIAGNOSTIC METHODOLOGY}

The method of diagnosis is the initial stage of model implementation. This will determine if the company you want to apply is ready and capable to do so. The test uses the following technique is performed in the following stages: 1) Assessment of technological component and 2) Evaluation of organizational factors (technical, administrative and commercial). Assessment of the technological component is based on the model proposed by the Research Group on electronic commerce in Colombia (GICOECOL) as a diagnostic tool that will analyze the technological critical variables inherent in any company wishing to implement a model of electronic commerce

The diagnosis methodology corresponds to a classification matrix (see Figure 4), whereby a company is classified into one of four possible categories, depending on the readiness index that is the same to implement e-business models and progress in implementing these within the organization. [12]

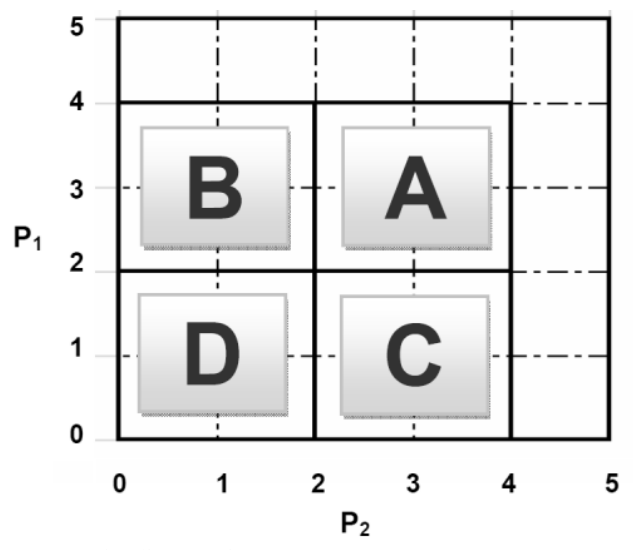

Fig. 4 Matrix diagnostic

Where $\mathrm{P}_{1}$ represents the readiness of the company for the implementation of ICT and / or electronic commerce y $\mathrm{P}_{2}$ is the value of progress in implementation of ICT and / or electronic commerce.

In the original methodology, the first stage evaluates the situation of the company in comparison with the economic sector in which it competes. However, for purposes of this project, modifications were made to the measurements of each of the variables, it is not necessary to compare the enterprise sector in which it competes.

In this vein, the stages for the application of the matrix, adapted to this project are:
1) Internal evaluation of the organization ( $Y$ axis).

2) Measurement of levels of implementation of e-commerce models ( $\mathrm{X}$ axis).

Internal evaluation of the organization aims to quantify the diagnosis of the company regarding its progress in ICTs and electronic commerce. This stage is divided into four (4) steps to get a proper diagnosis quantified: Evaluation of technological resources, Web Portal Assessment, Evaluation, Human Resources and eventually final internal evaluation of the organization.

For evaluation purposes the value zero (0) is the zero impact rating, the value one (1) corresponds to the rating of low impact, impact value two (2) corresponds to the average score, and the maximum value four (4) corresponds to the highest rating. This criterion applies to all assessments.

Evaluation of technological resources $\left(E_{R T}\right)$ is done based on the results of a questionnaire that seeks to quantify the computational resources such as computers, internet access, existence of a systems department, purchase of specific software, existence of databases, among other resources. This evaluation will yield a coefficient with value between zero (0) and four (4).

Web Portal Assessment $(E P W)$ is based on a second questionnaire in which the variables of the company's Web site, such as relevant content, ease of navigation, interactivity and graphic design among others, are qualified with the degree of compliance low, medium or high. Similarly, this ratio is obtained by correcting the value on a scale from zero (0) and four (4).

For the evaluation of Human Resources $(E R H)$, there is the classification of staff competencies in three (3) categories: 1. Those who have basic computer operations; 2. Those who manage their job-specific software, and 3. Those who are competent to Web 2.0 software development capability, as well as the capabilities of category 1 and 2 . From this, apply a new questionnaire to each employee of the organization to be assigned to one of these categories. For each category determines the number of employees needed to implement the model, depending on the product portfolio of the company and the number of stores in which you want to sell them. With these two facts, you get a coefficient for each category by dividing the number of employees available among the number of employees needed. Finally, average the three (3) coefficients and the average is multiplied by four (4) for the coefficient of human resources $(E R H)$ with a value between zero (0) and four (4).

The final internal evaluation of the organization is calculated by averaging the evaluations of technological resources, Web portal and Human resources, so you will get the grade of zero (0) to four (4) to be called P1. See Equation (1)

$$
P_{1}=\frac{E_{R T}+E_{P W}+E_{R H}}{3}
$$

Moreover, the second stage to assess the technology component, corresponds to the evaluation of levels of implementation of e-commerce, ie, progress in the use of electronic commerce for business interaction with the different 
International Journal of Artificial Intelligence and Interactive Multimedia, Vol. 1, $N^{o} 7$.

TABLE I

CUSTOMER REQUIREMENTS OF B2B E-COMMERCE MODEL IN COLOMBIA.

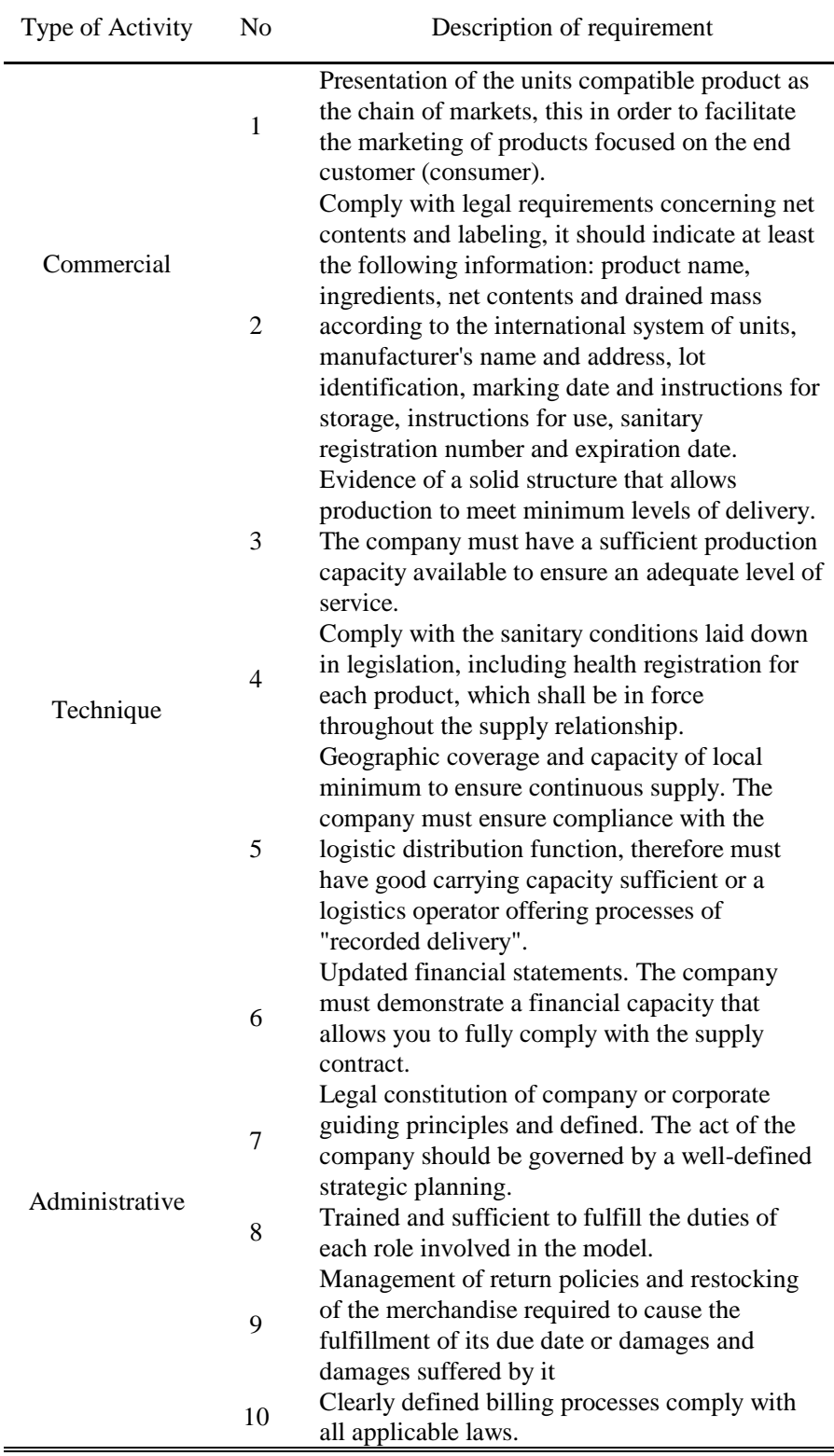

agents in their environment: Government, other companies, financial sector, customers, employees and suppliers.

This measurement of a new questionnaire, which the company will get a score of thirteen (13) and sixty-five (65) points. The higher the score, the progress in implementation of e-commerce is business. As is known, the evaluation of the company in the matrix of diagnosis is based on a score of one (1) to four (4), therefore it is necessary to correct this score to finally locate the assessment index $\mathrm{P} 2$ the matrix.

The second part of the diagnostic assess organizational factors. Of particular interest for our analysis the technical, commercial and administrative, which are directly associated with marketing and logistics components of any company, which together with the technological component, diagnosed earlier, are central to the model. These requirements are described in Table I: Customer requirements of B2B ecommerce model in Colombia
To diagnose the organizational variables, will be based on the requirements that customers have the model in Colombia, ie, chain stores and supermarkets.

For each type of requirement applies a questionnaire, so as to assess compliance with each requirement, and you get a score between zero (0) and ten (10) for each type of activity (commercial, technical and administrative).

After obtaining the coefficients of technical activities $(C A T)$, business $(C C)$ and administrative activities $(C A D)$, are weighted together with the technological coefficients $P_{1}$ y $P_{2}$, to obtain a total score consolidated company, which is between zero (0) and two hundred forty (240). Table II describes the diagnostic consolidated matrix

TABLE II

CONSOLIDATED MATRIX DIAGNOSIS

\begin{tabular}{cccc}
\hline \hline Coefficient & $\mathrm{P}_{1}$ & $\mathrm{P}_{2}$ & Total \\
\hline Commercial & $\mathrm{CC} * \mathrm{P}_{1}$ & $\mathrm{CC} * \mathrm{P}_{2}$ & $\boldsymbol{\Sigma}$ \\
$\begin{array}{c}\text { Activities }(\mathrm{CC}) \\
\text { Administrative } \\
\text { activities } \\
(\mathrm{CAD})\end{array}$ & $\mathrm{CAD}^{*} \mathrm{P}_{1}$ & $\mathrm{CAD}^{*} \mathrm{P}_{2}$ & $\mathbf{\Sigma}$ \\
Technical & $\mathrm{CAT}^{*} \mathrm{P}_{1}$ & $\mathrm{CAT}^{*} \mathrm{P}_{2}$ & $\mathbf{\Sigma}$ \\
activity (CAT) & Total & & \\
\hline \hline
\end{tabular}

In the column "Total", is located the summations of the results of the multiplications, as shown in the table, to finally get the total score will be critical for the implementation of the model, it will be the basis for categorizing the companies in three (3) categories.

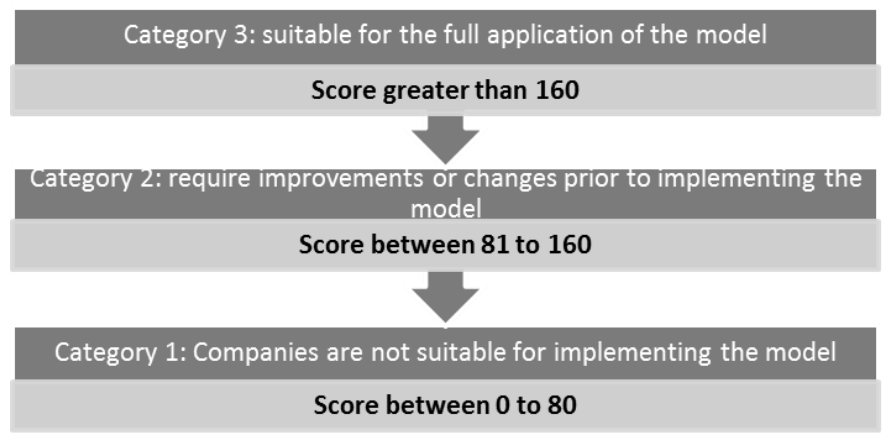

Fig. 5. Final classification of the companies evaluated

\section{PILOT TEST}

A pilot test was conducted in Bogota MSMEs. The results of the evaluation of each of the coefficients technological, administrative, technical and commercial summarized below, are present en table III next.

TABLE III

RESULTS OF EVALUATION OF TECHNOLOGY COMPONENTS

\begin{tabular}{cc}
\hline \hline $\begin{array}{c}\text { Technology Assessment Results Internal Rate } \\
\left(\mathrm{P}_{1}\right)\end{array}$ \\
\hline $\begin{array}{c}\text { Evaluation of technological } \\
\text { resources }\left(\mathrm{E}_{\mathrm{RT}}\right)\end{array}$ & 0,75 \\
$\begin{array}{c}\text { Web Portal Assessment } \\
\text { (EPW) }\end{array}$ & 0,00 \\
evaluation of Human \\
$\quad \begin{array}{c}\text { Resources }\left(\mathrm{E}_{\mathrm{RH}}\right) \\
\text { Average value } \mathrm{P}_{1}\end{array}$ & 0,00 \\
\hline
\end{tabular}




\begin{tabular}{cc}
\hline \multicolumn{2}{c}{$\begin{array}{c}\text { Results Coefficient Implementation of } \\
\text { Electronic Commerce }\left(\mathrm{P}_{2}\right)\end{array}$} \\
\hline $\begin{array}{c}\text { Score Electronic Commerce } \\
\text { (PCE) }\end{array}$ & 13 \\
Final value $\mathrm{P}_{2}$ & 0 \\
\hline \hline
\end{tabular}

TABLE IV

RESULTS OF EVALUATION OF BUSINESS

\begin{tabular}{lccc}
\hline \hline \multicolumn{4}{c}{ Summary of results evaluation ratio of commercial activities (CC) } \\
\hline Product & Requirement 1 & Requirement 5 & $\mathrm{CCi}$ \\
\hline $\begin{array}{l}\text { Bocadillo } \\
\text { veleño }\end{array}$ & 10 & 5 & 7,5 \\
$\begin{array}{l}\text { Lonja de } \\
\text { bocadillo }\end{array}$ & 10 & 6,25 & 8,125 \\
Herpo & 10 & 8,75 & 9,375 \\
$\begin{array}{l}\text { Dulce de breva } \\
\text { Arequipe }\end{array}$ & 0 & 8,75 & 4,375 \\
industrial & & 5 & 2,5 \\
$\begin{array}{l}\text { Glasse } \\
\text { industrial }\end{array}$ & 0 & 5 & 2,5 \\
$\begin{array}{l}\text { Bocadillo } \\
\text { industrial }\end{array}$ & 0 & 5 & 2,5 \\
\hline \multicolumn{2}{l}{} \\
\hline \hline
\end{tabular}

In the tables (IV, V,VI and VII) are present the information obtained of pilot test

TABLE V

RESULTS OF EVALUATION OF TECHNICAL ACTIVITIES

\begin{tabular}{lc}
\hline \hline \multicolumn{2}{c}{$\begin{array}{c}\text { Summary of results of technical activities } \\
\text { evaluation ratio (CAT) }\end{array}$} \\
\hline $\begin{array}{l}\text { Geographic Coverage Ratio } \\
\quad \text { (CCG) }\end{array}$ & 0 \\
$\begin{array}{l}\text { Coefficient of Health } \\
\text { Registry (CRS) }\end{array}$ & 0 \\
$\begin{array}{l}\text { Unused capacity (CNU) } \\
\text { Coefficient of technical } \\
\text { activities (CAT) }\end{array}$ & 9,57 \\
\hline \hline
\end{tabular}

TABLE VI

EVALUATION RESULTS OF ADMINISTRATIVE

Summary of results of administrative evaluation rate (CAD)

Requirement 2: Financial
Statements

Requirement 7: Legal constitution of company and corporate

6,66666667

principles

Requirement 8: Trained personnel

and sufficient

Requirement 9: Handling return

policies

Requirement 10: Billing processes

defined

Average value Coefficient

Administrative Activities (CAD)

TABLE VII

SUMMARY FINAL DIAGNOSIS

\begin{tabular}{cccc}
\hline \hline Coefficient & $\mathrm{P}_{1}=0,25$ & $\begin{array}{c}\mathrm{P}_{2}= \\
0\end{array}$ & Total \\
\hline $\begin{array}{c}\text { Commercial } \\
\text { Activities (CC) }\end{array}$ & $\mathrm{CC} * \mathrm{P}_{1=1} 1,3169$ & 0 & 1,3169 \\
$\begin{array}{c}\text { Administrative } \\
\text { activities }\end{array}$ & $\mathrm{CAD} * \mathrm{P}_{1=0,8333}$ & 0 & 0,8333 \\
\hline
\end{tabular}

\begin{tabular}{clll}
\hline $\begin{array}{c}(\mathrm{CAD}) \\
\text { Technical } \\
\text { activity (CAT) }\end{array}$ & CAT*P $_{1=} 0,7976$ & 0 & 0,7976 \\
& Total & & 2.9472 \\
\hline \hline
\end{tabular}

The total weighted score for the firm diagnosis was two point ninety-four (2.94) which places him in category one (1), meaning that the company is not discussed in adequate conditions to implement the model e-commerce now.

The critical factor in obtaining this result are the poor of ICTs in that the company has, so it is recommended that initial investments in this field, also for the poor level of ownership of e-business models in the company is recommended training for employees in the use of computational tools and generate added value to the administrative processes of the company.

\begin{tabular}{c}
\hline V.DESIGN AND IMPLEMENTATION OF THE MODEL \\
CHARACTERIZATION
\end{tabular}

The model of innovative processes that make use of electronic commerce as tools discussed in this document requires that companies wishing to implement meet the following conditions: Register in organization dedicated to the control and monitoring the quality and safety of food and pharmaceutical products in Colombia (INVIMA) all products to market, obtaining the standard Bar Codes for the products to market, acquisition and certification of EDI mailbox E-com GS1, recruitment or training of skilled personnel for ecommerce platform, CEN Affiliation software transactional EDI transmission and acquisition of specific software to create barcode EAN 14.

Once you have met the requirements for marketing, you can implement the model. The process begins with the creation and transmission of the document PRICAT, and culminates with the delivery and return notices. The fig., 6 describes the activities proposed

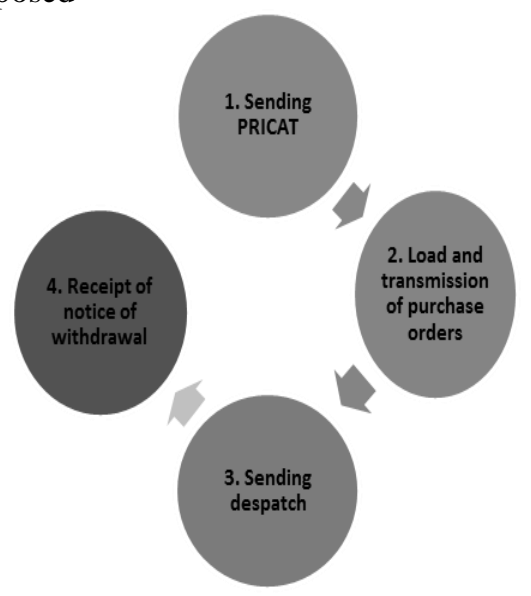

Fig. 6. Marketing process through E-com standard documents of GS1

The procedure for creating and sending the PRICAT consists of the following stages:

1) Implementation of selected software.

2) Sending a letter and attached documents.

3) Dealing with the chain (customer).

4) Development and Shipping PRICAT 
Sending PRICAT's will be necessary for the addition of new references (products), changes in existing prices or the withdrawal thereof. This will be done by the senior management of the organization and the administrator of the ecommerce platform.

After this, proceed with the preparation and transmission load of orders, the following procedure:

1) Load and transmission of purchase order.

2) Download and validation of the data associated with purchase orders.

The agents involved in this stage are the agent and manager of e-commerce platform.

The next step is to prepare and dispatch advices. For the preparation of this document should make reference to the orders received and the total quantities per order to ship. The procedure starts with the implementation of specific software for generating warnings office with a bar code to thereby generate the document itself. The software implementation is performed by the senior management and the completion and submission of dispatch by the administrator of e-commerce platform.

Finally, the procedure for receiving notice of withdrawal is as follows:

1) Receipt of notice.

2) Analysis and monitoring it.

For the preparation of this document should make reference to the orders received and the total quantities per order to ship. The agent involved in the management of refund notices are the administrator of the e-commerce platform and Key Account Manager (KAM).

\section{CONCLUSION}

The government plans for the technological inclusion of micro, small and medium businesses included both in the National Development Plan, as in the plan MSMEs digital 2009 , opening the possibility of obtaining the necessary funding for implementation of ICTs that support e-business models, facilitating the acquisition of software and hardware to improve the processes involved in managing the supply chain, resulting in more competitive and efficient companies.

Likewise, certification to international GS1 standards enable companies to restructure their logistics processes, thus becoming a tool to increase their ability to seek new markets and channels for marketing their products. [1*]

Critical to implementing innovative processes supported by e-business models is the appropriation of ICTs by the company and human resource training in the use of these tools, which can be checked in detail by the results obtained in the pilot test, where low scores in these areas not determined the feasibility of implementing the proposed model in the selected company.

For this reason, it is important to note that the implementation of innovative processes supported by the proposed e-commerce model, it is necessary for companies to appropriate knowledge management models that allow the previous experience in the use of technological resources and tools that facilitate the appropriation of concepts and procedures outlined in this document.

\section{REFERENCES}

[1] K. Laudon and L. Jane, Sistemas de Información Gerencial, Pearson Prentice Hall, 2004.

[2] M. Dell, Collaboration equals innovation InformationWeek, Manhasset, 2003, Jan 27.

[2] G. Tarazona and V. Medina, "Generación de Valor en la Gestión de Conocimiento," in Seventh Laccei Latin American and Caribbean Conference for Engineering and Technology, San Cristobal, Venezuela, 2009.

[4] D. Teece, "Business Models, Business Strategy and Innovation," Long Range Planning, pp. 172 - 194, 2010.

[5] T. Koupluspoulos and C. Frappaolo, Lo Fundamental y lo más efectivo de la Gerencia del Conocimiento, McGraw Hill Iteramericana S.A, 200.

[6] J.-M. Nurmilaakso, "EDI, XML and e-business frameworks: A survey," COMPUTERS IN INDUSTRY, pp. 370 - 379, 2008.

[7] F. Hayes, "The story so far: e-commerce," COMPUTERWORDL, 2002.

[8] T. Benson, PRINCIPLES OF HEALTH INTEROPERABILITY HL7 AND SNOMED Health Information Technology Standards, London: Springer, 2010.

[9] ediversa, "GUIA DE IMPLANTACIÓN PRICAT D.96A VERSION 2," EDIVERSA, Barcelona, 2006.

[10] HYPERLINK "http://web.invima.gov.co/" http://web.invima.gov.co Consultado el 26 de septiembre de 2012

[11] HYPERLINK "http://www.cabasnet.org/" http://www.cabasnet.org/ Consultado el 15 de agosto 2012

[12] D. Barrera, G. Diana and G. Tarazona, Propuesta Metodologica De Evaluación Previa A La Implementación De Modelos De Comercio Electronico, Bogota: Universidad Distrital Francisco Jose De Caldas, 2008.

Tarazona, Giovanny. Doctoral candidate in systems and computer services for internet in the Oviedo University, Asturias, Spain (2012) - diploma of advanced studies November 2007 Pontifical Salamanca University in campus Madrid Spain, Specialization in computer project (2006), Specialization in engineering software (1999). He is Industrial engineer, Francisco José de Caldas District University, Bogota, DC, (1998). He is Full Time Professor Francisco José de Caldas District University- Faculty of Engineering since July 2003. He is founding member of KAIZEN PBT GROUP Ltda, legal representative, director of several projects, Bogotá, DC, 1996 - December 2011. Director Research Group on Electronic Commerce Colombian GICOECOL Francisco José de Caldas District University, Director of several research projects.

Rodriguez, Luz Andrea: Master Engineering and website design (2012), Specialization in hygiene and occupational health (2010), Industrial Engineer, Francisco José de Caldas District University, Bogota, DC, (2008). She is Full Time Professor Foundation Liberators University (August 2011- May 2012) Area Production. She is full professor in occupational health at INPAHU (August 2010-May 2011). Director project Research "Strategies for Strengthening of Information System Tourism Health in Bogota".

Pelayo G-Bustelo, B. Cristina is a Lecturer in the Computer Science Department of the University of Oviedo. She is Ph.D. from the University of Oviedo in Computer Engineering. Her research interests include ObjectOriented Technology, Web Engineering, eGovernment, Modeling Software with BPM, DSL and MDA.

Sanjuán Martínez, Oscar is a Lecturer in the Computer Science Department of the University of Oviedo. He is Ph.D. from the Pontifical University of Salamanca in Computer Engineering. His research interests include ObjectOriented technology, Web Engineering, Software Agents, Modeling Software with BPM, DSL and MDA. 